\section{Monument to the discoveries}

\author{
John Launer
}

A week ago I was standing with my wife by the River Tagus in Lisbon, next to the Monument to the Discoveries. The monument is at the spot where Vasco da Gama set out to discover the southeast passage from Europe to Asia, past the Cape of Good Hope. Vasco's discovery marked the beginning of the Portuguese maritime empire. At the furthest tip of Europe, Portugal was perfectly situated to found such an empire. As well as conquering parts of Africa, they gained footholds in China and India, and colonised Brazil on the other side of the Atlantic. Whether or not the Africans, Chinese, Indians or South Americans ever appreciated being 'discovered', Portugal established the first global village where everyone spoke the same language. ${ }^{1}$ It was relatively short-lived, and never equalled the wealth of the Spanish and British empires that succeeded it. Nevertheless, it began the European domination of every other continent on the planet from 16th to 20 th century.

Visiting the monument, I was struck by a peculiar irony. Just as Portugal once led to the rise of Europe, it now appears to be leading our decline. In recent years, the Portuguese government has become the first in western Europe to be unable to raise loans in the international bond market. It has had to receive a bail-out from the European Central Bank, and to undertake a fierce 'austerity programme' of cuts in pensions and the public sector, including its health service. Ireland and Greece have followed in Portugal's wake, with probably more countries to come. Although it would be nice to see these recent events as a temporary blip in the continent's fortunes, it is probably more realistic to interpret what is happening as the end of half a millennium of continuous economic expansion in western Europe. Perhaps the tactics of our governments may succeed in delaying the process by a few years. However it would be foolish to believe that western Europe can avoid a relative decline on the global scene. Ironically, it is the countries that Portugal first 'discovered'-China, India

Correspondence to Dr John Launer, London Deanery, Stewart House, London WC1B 5DN, UK;

jlauner@londondeanery.ac.uk and Brazil-that now have the fastest economic growth in the world. Economists predict that they will be the dominant nations on earth for the next 100 years.

\section{PRIVILEGED ACCESS}

The shift in global wealth and power is likely to affect every aspect of our lives, and this includes our health services. For those of us working as doctors in the western world (including the USA as well as Europe) it is worth thinking about the implications of these realities. We are likely to be living in a world where we can no longer depend on privileged access to the world's natural resources, and on political or economic power over much of its population. In consequence, we probably cannot expect our own high incomes and guaranteed health and social welfare systems to continue indefinitely as they are. How will we manage our health services, for example, if the differential in wealth between west and east lessens, or even reverses? Here are some ideas we may need to consider.

First, we need to keep seeing events in a long term historical context. At the moment it is easy to blame our economic predicament on local or recent events-for example, the policies of our current administration, or the mistakes of neighbouring countries. There is no reason to take such a limited perspective. Instead of focusing on short-term political fashions, health service researchers, economists and planners should start to think seriously in a time frame of 50-100 years, and a context of global developments. Doctors who are in early or mid-career may need to imagine the kinds of skills and adaptability they will need to work in very different environments, or even in a number of different countries.

\section{COST EFFECTIVE}

Connected with this, it is time for doctors to insist that we can no longer sustain health services that are centred on capitalintensive hospital care. We should challenge the interest groups that divert money from general practice and community clinics into expensive technology and pharmaceuticals that margin- ally prolong a few lives, but at the cost of overall improvements in public health. The arguments showing that investment in primary care is more cost effective in terms of health outcome are conclusive. ${ }^{2}$ Regardless of which sector of the health service we work in, we should take these arguments seriously.

Even more important is the issue of education. When I went to medical school it was almost universally accepted that places at university should be free, and that students should receive grants so that they could focus on their studies. These principles have vanished so completely that most undergraduates probably have no idea that their own teachers benefitted from them. There are two main risks from this change in funding for higher education. One is the danger of a relatively uneducated workforce-at exactly the time when we need a high level of intellectual and technical capacity to compensate for losing our material capital. The other risk lies in the widening social and health differentials that occur when poorer people have to withdraw from the world of higher education. These differentials are an affront to social justice. Evidence shows that they also drag nations down collectively in terms of their overall health. ${ }^{3}$ If we invest our limited resources in one thing only, it should be to reverse this trend.

\section{PREVENTING DECLINE}

There is one additional factor to think about, and it matters more than anything else. The economic crisis in the west is happening at the same time as two other crises: the exhaustion of our reserves of fossil fuel, and the climate change resulting from the combustion of the fuel that still remains. If the west currently has one advantage, it is the research and technological potential to tackle these issues and overcome them. Carbon-neutral technology is the one thing that could really put a brake on the decline of our services. It could also help us to provide resources for the countries that are now displacing us on the world scene. We could then help them to avoid declining in their turn.

I was a school child when I last visited Lisbon, and the Monument to the Discoveries. At that time, the last of the European maritime empires-the British one-was only just beginning to shrink. The pages in our school atlas had large areas of pink, denoting the countries that were still under British rule, or had been so when the atlas was printed. Returning to 
the same spot in Portugal after nearly 50 years, the world seems very different indeed. We may be approaching the end of a huge historical cycle that began at this place. But there is still time to make the right decisions collectively, so that our children and grandchildren have a health service that is resilient enough to survive the turbulence that may be ahead of us in Europe.

Competing interests None.

Provenance and peer review Commissioned; internally peer reviewed.

Postgrad Med J 2012;88:55-56.

doi:10.1136/postgradmedj-2011-130648

\section{REFERENCES}

1. Page M. The First Global Village: How Portugal Changed the World. Lisbon: Casa das Letras, 2007.

2. Starfield B, Shi L, Macinko J. Contribution of primary care to health systems and health. Milbank 0 2005:83:457-502.

3. Wilkinson R, Pickett K. The Spirit Level: Why Equality is Better for Everyone. 2nd edn. London: Allen Lane, 2010. 